\title{
Systematic Review: A Comparison between Vancomycin and Daptomycin for Sepsis Infection Antibiotic Therapy
}

\author{
Ratih Puspita Febrinasari ${ }^{1 *} \mathbb{D}$, Benedictus Benedictus $^{2}$, Akhmad Azmiardi $^{3,4}$ (D) \\ ${ }^{1}$ Department of Pharmacology, Faculty of Medicine, Universitas Sebelas Maret, Surakarta, Indonesia; ${ }^{2}$ Graduate Programme, \\ Faculty of Medicine, Universitas Sebelas Maret, Surakarta, Indonesia; ${ }^{3}$ Doctoral Program of Public Health, Universitas Sebelas \\ Maret, Surakarta, Indonesia; ${ }^{4}$ Department of Public Health, Faculty of Public Health, Universitas Veteran Bangun Nusantara, \\ Sukoharjo, Indonesia
}

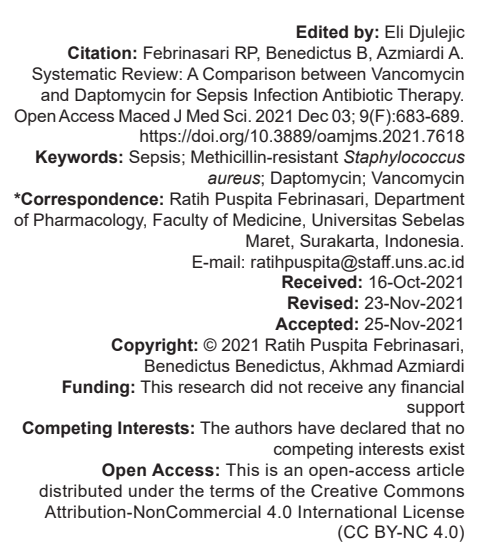

Introduction

Sepsis is a life-threatening condition characterized by organ dysfunction caused by immune system dysregulation after infection [1]. Based on the data from the World Health Organization (WHO) in 2018, the prevalence of sepsis is 30 million cases per year, which leads to 6 million deaths per year globally. Most sepsis cases around the world emerge from low to middle economic outcome countries [2], [3].

One of the most frequent bacteria with antibiotic resistance that can cause sepsis is Methicillin-resistant Staphylococcus aureus (MRSA) [4]. Globally, the mean prevalence of MRSA infection is $17.4 \%$ from all kinds of infection. In the USA, MRSA infected $31.8 / 100,000$ populations, and $75 \%$ of infections resulting in bacteremia that can develop into sepsis [5], [6]. The WHO stated that MRSA is one of the high-priority bacteria for new antibiotics research and development [7].

Based on the IDSA guideline in 2020, the first-line therapy for sepsis is vancomycin or daptomycin [8]. However, recently, some MRSA strains were found resistant to vancomycin [9], [10]. Casapao et al. (2013) also found a strain that is sensitive to vancomycin therapy during the microbiology sensitivity test becomes resistant to in vivo. The threat of antibiotic resistance makes a review needed to assess the effectiveness of vancomycin for sepsis first-line therapy compared to daptomycin [9]. This study aimed to review comparison between vancomycin and daptomycin for sepsis infection antibiotics therapy.

\section{Materials and Methods}

\section{Study design}

This review was reported using the "Preferred Reporting Items for Systematic Reviews and MetaAnalysis" guideline and written using the "Synthesis without Meta-Analysis" method. This systematic review was designed to answer the question of whether there is a different result between the treatment with vancomycin and daptomycin in patients with sepsis infection. This 
Table 1: Summary of included studies

\begin{tabular}{|c|c|c|c|c|c|c|c|c|c|c|}
\hline First Author, Year & $\begin{array}{l}\text { Research } \\
\text { location }\end{array}$ & Study type & Sample population & Antibiotics treatment & $\begin{array}{l}\text { Total } \\
\text { patients }\end{array}$ & $\begin{array}{l}\text { Sepsis } \\
\text { patient }\end{array}$ & $\begin{array}{l}\text { Patients receiving } \\
\text { vancomycin/ } \\
\text { daptomycin }\end{array}$ & Mortality & $\begin{array}{l}\text { Failure of } \\
\text { treatment }\end{array}$ & $\begin{array}{l}\text { Mean } \\
\text { Jadad } \\
\text { score }\end{array}$ \\
\hline $\begin{array}{l}\text { Sundalic et al., } \\
2020\end{array}$ & Croatia & $\begin{array}{l}\text { Prospective single center } \\
\text { open-label Randomized } \\
\text { controlled trial }\end{array}$ & $\begin{array}{l}\text { Patient aged } \geq 18 \\
\text { years old, with } \\
\text { resistance strain } \\
\text { Gram-positive } \\
\text { bacterial infection } \\
\text { from blood culture }\end{array}$ & Vancomycin & 74 & 11 & 24 & 4 & - & 2.5 \\
\hline Paul et al., 2015 & Israel & $\begin{array}{l}\text { Multicenter open label } \\
\text { randomized controlled } \\
\text { trial }\end{array}$ & $\begin{array}{l}\text { All patient } \\
\text { suspected or } \\
\text { infected with } \\
\text { MRSA }\end{array}$ & Vancomycin & 252 & 91 & 117 & 13 & 32 & 2 \\
\hline $\begin{array}{l}\text { Emonet et al., } \\
2016\end{array}$ & Switzerland & $\begin{array}{l}\text { Single-center open } \\
\text { parallel Randomized } \\
\text { controlled trial }\end{array}$ & $\begin{array}{l}\text { Patient aged } \geq 18 \\
\text { years old, with } \\
\text { positive culture } \\
\text { of Gram-positive } \\
\text { bacteria }\end{array}$ & Vancomycin & 89 & 33 & 35 & $\begin{array}{l}15 \\
\text { (from all } \\
\text { research } \\
\text { patient) }\end{array}$ & $\begin{array}{l}33 \\
\text { (from all } \\
\text { research } \\
\text { patient) }\end{array}$ & 2.5 \\
\hline $\begin{array}{l}\text { Niederman et al., } \\
2014\end{array}$ & $\begin{array}{l}\text { USA, Asia, } \\
\text { Europa, } \\
\text { Latin } \\
\text { Americans }\end{array}$ & $\begin{array}{l}\text { Phase IV, double-blind, } \\
\text { randomized, } \\
\text { comparator-controlled, } \\
\text { multicenter trial }\end{array}$ & - & Vancomycin & 448 & 35 & 224 & - & - & 2.5 \\
\hline $\begin{array}{l}\text { Fowler et al., } \\
2020\end{array}$ & $\begin{array}{l}11 \text { countries } \\
\text { ( } 79.3 \% \text { from } \\
\text { the USA) }\end{array}$ & $\begin{array}{l}\text { Randomized, double } \\
\text { blind, placebo-controlled, } \\
\text { superiority design }\end{array}$ & $\begin{array}{l}\text { Patient aged } \geq 18 \\
\text { years old }\end{array}$ & $\begin{array}{l}\text { Vancomycin } \\
\text { Daptomycin } \\
\text { Vancomycin+Exebacase } \\
\text { Daptomycin+Exebacase }\end{array}$ & $\begin{array}{l}45 \\
71\end{array}$ & $\begin{array}{l}13 \\
17\end{array}$ & $\begin{array}{l}13 \\
3 \\
21 \\
5\end{array}$ & $\begin{array}{l}8 \\
8\end{array}$ & - & 4 \\
\hline $\begin{array}{l}\text { Berthaud et al., } \\
2019\end{array}$ & Paris & $\begin{array}{l}\text { Open-label 1:1 } \\
\text { randomized controlled } \\
\text { trial }\end{array}$ & $\begin{array}{l}\text { Patients aged } \\
3-17 \text { years old }\end{array}$ & Vancomycin & 99 & 8 & 99 & - & - & 3 \\
\hline $\begin{array}{l}\text { Chytra et al., } \\
2012\end{array}$ & $\begin{array}{l}\text { Czech } \\
\text { Republic }\end{array}$ & $\begin{array}{l}\text { Single center, } \\
\text { prospective, randomized, } \\
\text { open label comparative } \\
\text { study }\end{array}$ & $\begin{array}{l}\text { Patient aged } \geq 18 \\
\text { years old }\end{array}$ & Meropenem+Vancomycin & 240 & 214 & 12 & $\begin{array}{l}36 \\
\text { (from all } \\
\text { research } \\
\text { patient) }\end{array}$ & 45 & 2.5 \\
\hline
\end{tabular}

question includes the information of population (patient with sepsis caused by MRSA), intervention (vancomycin or daptomycin), and outcomes (mortality).

\section{Eligibility criteria}

The included studies for this review were following several criteria, including randomized controlled trial (RCT), English language articles, using vancomycin or daptomycin as treatment, and investigating sepsis patients caused by MRSA infection. The study was excluded if it was a non-randomized control trial, did not use vancomycin or daptomycin, and had an inappropriate population. In addition, duplicate publications, observational studies, review studies, and case reports were excluded from the study.

\section{Search strategy}

The included studies for this systematic review were collected from three online databases including PubMed, ProQuest, and ScienceDirect published between 2011 and 2020 in the English language. The keywords used for this systematic review were "sepsis," "shock septic," "MRSA," "vancomycin," and "daptomycin." These keywords were utilized in combination to search all these databases for relevant literature.

\section{Study selection}

Two authors were independently screening the collected articles. Any disagreement was resolved by discussion. The inclusion criteria were according to population, interventions, comparators, and outcomes, that is, the population of patients with MRSA, intervention, and comparison of daptomycin or linezolid, and the outcome of mortality.

\section{Data extraction and quality assessment}

The data from the selected studies were extracted by two independent authors independently. Any disagreement was resolved by discussion to reach a consensus. The collected data included the author's last name, year of study, location of study, the number of participants, type of treatment, and mortality outcome. The critical appraisal used in this review was Jadad Scoring.

\section{Results}

Figure 1 shows the process of selecting relevant studies. The seven studies were included in this systematic review with a total of 1316 patients. The characteristics of the studies are presented in Table 1. All studies were published from 2010 to 2020 and were of randomized control trial designs. Two studies were conducted in multination and five studies in a single nation, including Croatia, Israel, Swiss, France, and the Czech Republic. The sample size of included studies ranges from 45 to 448 participants. Four studies only used vancomycin treatment; two studies used a 


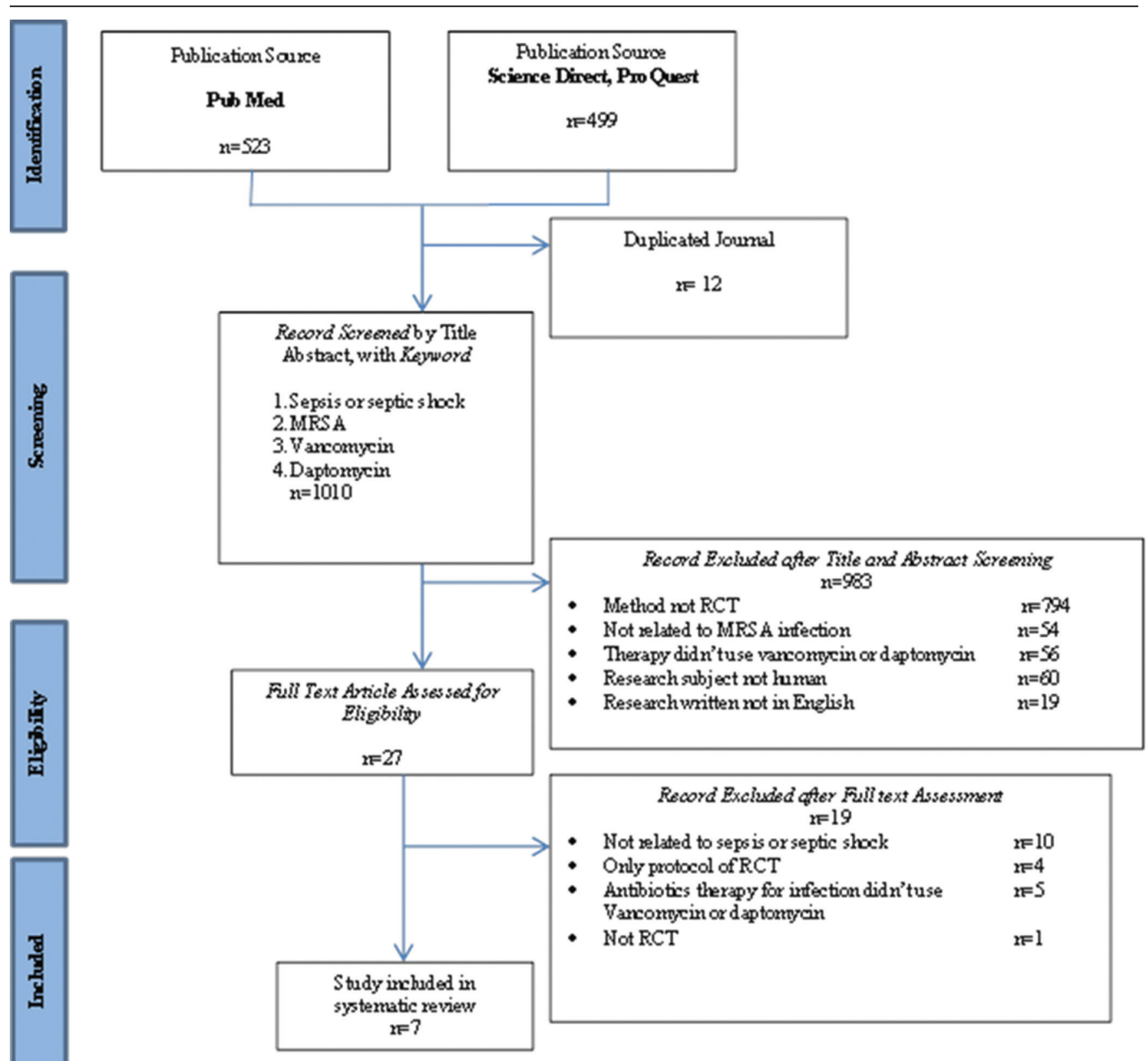

Figure 1: Flow diagram of the research procedure

combination of vancomycin and daptomycin, and the other used vancomycin plus meropenem as the treatment. Patient mortality was included in five studies with the number of deaths ranging from 4 to 36 while two studies did not show the number of deaths.

Most of the journals included in this review were open-label RCT, except for single double-blind RCT studies.

\section{Discussion}

In this systematic review, the difference in the effectiveness between vancomycin and daptomycin for sepsis caused by MRSA could not be compared since there was a lack of RCT studies found in databases that directly compared the use of vancomycin and daptomycin. Most RCT used vancomycin as the primary therapy [11], [12], [13], [14], [15], [16]. Although daptomycin has been included in the guideline for bloodstream infection caused by MRSA and has better efficacy than vancomycin, there is still a lack of RCT studies using daptomycin for sepsis treatment [8], [17], [18], [19]. In this systematic review, the use of daptomycin was only found in one RCT and was not used as the primary or comparison treatment in the research [19].

Although there was a lack of RCT about the daptomycin usage for sepsis treatment, there are some case reports about daptomycin use found during journal preview in this systematic review. Based on the compilation of 26 case reports between 2011 and 2012, 
the failure of the first-line therapy using vancomycin 101 will result in the futility of daptomycin therapy. Most of the futilities occur when the minimum inhibitory concentration of vancomycin needed is greater than one. However, the combination of daptomycin and cefazoline will offer a successful therapy [20].

The mortality rate of sepsis patients caused by MRSA infection based on the journal articles included in this systematic review was $11.1-50 \%$, and the failure rate of vancomycin therapy was 18.8-27.4\% [12], [16], [21]. The mortality rate of sepsis patients caused by MRSA lies between $20 \%$ and $30 \%$. Most of the studies included in this systematic review showed better outcomes of vancomycin therapies except for one study from America [21], [22]. These outcomes could have resulted from the difference in the prevalence of MRSA bacteria included in vancomycin-resistant $S$. aureus (VRSA), vancomycin intermediate $S$. aureus (VISA), or heterogeneous VISA (hVISA) between America and another continent. In America, the prevalence of VRSA, VISA, or hVISA is $3.6 \%$ while in Asia and Europe, the prevalence is $1.2 \%$ and $1.1 \%$, respectively [23].

Many factors contribute to the failure of vancomycin therapy. Some of them correlate with the serum concentration of vancomycin during medication. Based on the guideline, the target vancomycin serum concentration is $15-20 \mathrm{mg} / \mathrm{l}$. Low vancomycin serum concentration during treatment of $<10 \mathrm{mg} / \mathrm{l}$ is associated with the presence of vancomycin-resistant strain bacteria [24]. Patients with serum vancomycin concordant to the target of area under the curve/minimum inhibitory concentration $>400$ in $24 \mathrm{~h}$ will likely have a $53 \%$ lower mortality rate and a $61 \%$ lower therapy failure rate [25].

From the data collected in this systematic review that presented in Table 2, the attainment of the target vancomycin serum concentration is still low. Sundalic et al. (2020) suggest only five out of 24 patients reach target vancomycin serum in $24 \mathrm{~h}$ while Paul et al. (2015) show that the median of vancomycin serum concentration in 117 patients is only $14.9 \mathrm{mg} / \mathrm{l}$ [11], [12]. Low vancomycin serum concentration during treatment is probably caused by an increase in the excretion rate in sepsis patients. In severe disorders like sepsis, the body volume distribution will be very high, which leads to escalation in the drug excretion rate [26]. On the other hand, Berthaud et al. (2019) show that altered vancomycin dose using Bayesian methods could increase the rate of patients achieving the target vancomycin serum concentration [15].

One of the side effects caused by vancomycin use is the emergence of renal damage because of vancomycin nephrotoxic properties [27]. The independent factor correlated with renal failure is the reach of vancomycin serum concentration of $\geq 15 \mathrm{mg} / \mathrm{l}$ while the target vancomycin serum treatment is 15-20 mg/l [24], [28], [29], [30], [31]. This problem shows the dilemma of sepsis or septic shock medication. It is caused by the increase in renal damage because of the disorder and medication. Apart from the increase in renal injury, the failure in renal function during sepsis or septic shock medication leads to an escalation of expenditure cost of approximately $\$ 52,257$ [14].

Vancomycin can be combined with another antimicrobial treatment to tackle antibiotics resistance.

Table 2: Impact of Vancomycin usage during therapy

\begin{tabular}{|c|c|c|c|c|}
\hline First Author, Year & Duration of Therapy & Vancomycin serum concentration & AKI/Kidney failure cases & Other founding \\
\hline Sundalic et al., 2020 & $15-32.5$ days & $\begin{array}{l}\cdot \text { Only five patients reached the concentration } \\
\text { target of } 15-20 \mathrm{mg} / \mathrm{L} \text { in } 12 \mathrm{~h} \\
\cdot 17 \text { patients reached the target concentration of } \\
15-20 \mathrm{mg} / \mathrm{L} \text { in } 72 \mathrm{~h}\end{array}$ & $\begin{array}{l}\text { Eight patients from all } \\
\text { research sample }\end{array}$ & - \\
\hline Paul et al., 2015 & $11-28$ days & $\begin{array}{l}10.4-21 \text { (median } 14.9 \text { ) From } 97 \text { patients } \\
\text { whose serum vancomycin concentrations were } \\
\text { measured, only } 80 \text { patients reached the target } \\
\text { of }>10 \mathrm{mg} / \mathrm{L}\end{array}$ & - & 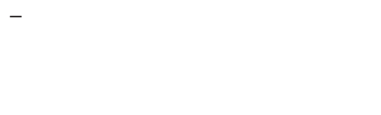 \\
\hline \multirow[t]{2}{*}{ Emonet et al., 2016} & $\begin{array}{l}15-36 \text { days (definitive antibiotics } \\
\text { administration in } 5 \text { hours after } \\
\text { detection) }\end{array}$ & - & - & \multirow{2}{*}{$\begin{array}{l}\text { Bacteriology examination with PCR } \\
\text { shows faster the result compared to } \\
\text { standard examination ( } 3.9 \text { vs. } 25.4 \mathrm{~h} \text { ), } \\
\text { but earlier administration of specific } \\
\text { therapy does not affect the patient's } \\
\text { mortality }\end{array}$} \\
\hline & $\begin{array}{l}11.3-30.3 \text { days (definitive } \\
\text { antibiotics administration in } 25.5 \\
\text { h after detection) }\end{array}$ & - & 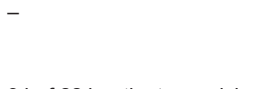 & \\
\hline Niederman et al., 2014 & 23.6 days (mean) & - & $\begin{array}{l}34 \text { of } 224 \text { patients receiving } \\
\text { vancomycin develop kidney } \\
\text { failure }\end{array}$ & $\begin{array}{l}\text { Patients who developed kidney failure } \\
\text { from the vancomycin therapy spent } \\
\$ 52,257 \text {, compared to those who did } \\
\text { not develop kidney failure spending } \\
\$ 29,923\end{array}$ \\
\hline \multirow[t]{2}{*}{ Fowler et al., 2020} & $\begin{array}{l}31.3 \text { days (mean) (Antibiotics } \\
\text { only) }\end{array}$ & - & - & \\
\hline & $\begin{array}{l}36.6 \text { days (mean) } \\
\text { (antibiotics+Exebacase) }\end{array}$ & 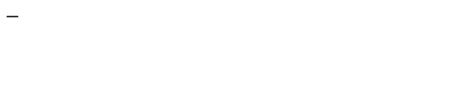 & - & \multirow{3}{*}{$\begin{array}{l}\text { Additional therapy with Exebacase } \\
\text { produced a better result of } 42.8 \% \\
\text { compared to the antibiotics-only therapy } \\
\text { Compared to standard dosing, dosing } \\
\text { using The bayesian calculation provides } \\
\text { significant results in achieving the } \\
\text { target serum vancomycin concentration } \\
\text { in } 24 \mathrm{~h}\end{array}$} \\
\hline Berthaud et al., 2019 & - & $\begin{array}{l}\text { AUC } 0-24 / \mathrm{MIC}>400 \text { and AUC } 0-24 / \\
\text { MIC }<800=34 ; \text { Reach the target concentration of } \\
20-40 \mathrm{mg} / \text { liter=27 (Bayesian dose) }\end{array}$ & - & \\
\hline & - & $\begin{array}{l}\text { AUC } 0-24 / \mathrm{MIC}>400 \text { and AUC } 0-24 / \\
\text { MIC }<800=24 ; \text { reaching the target concentration } \\
\text { of } 20-40 \mathrm{mg} / \mathrm{l}=16 \text { (normal dose) }\end{array}$ & - & \\
\hline \multirow[t]{2}{*}{ Chytra et al., 2012} & 18-39 days (infusion) & - & - & \multirow{2}{*}{$\begin{array}{l}\text { Antibiotics administration via infusion or } \\
\text { bolus produced a clinically insignificant } \\
\text { result, but infusion showed a higher } \\
\text { efficacy level of antimicrobial therapy }\end{array}$} \\
\hline & 14-42 days (bolus) & - & - & \\
\hline
\end{tabular}


One of the drugs that can be used in combination with vancomycin is Exebacase, which is an anti-staphylococcal lysin [32], [33]. Exebacase is an antimicrobial drug that is not in the antibiotics class. This drug acts as peptidoglycan hydroxylase that synergically works with antibiotics to destroys biofilm produced by bacteria and decrease the rate of bacteria resistance to antibiotics [32], [33], [34], [35]. Fowler et al. (2020) found that Exebacase combined with vancomycin or daptomycin will increase the effectivity of therapy up to $42.8 \%$, compared to a medication using vancomycin or daptomycin only [21].

\section{Conclusions}

Because of the lack of RCT journal articles about the experiment of daptomycin usage for sepsis treatment caused by MRSA infection, this research cannot compare the effectiveness between vancomycin and daptomycin. However, from some case reports included in this research, there is evidence that the usage of daptomycin base after vancomycin treatment failure will cause another treatment failure. Based on the data collected from several RCT included, the usage of vancomycin for sepsis therapy caused by MRSA infection is still viable although several factors affect the effectiveness of the therapy.

\section{Acknowledgment}

The authors would like to thank the Faculty of Medicine Universitas Sebelas Maret, Surakarta, for supporting this publication.

\section{Declarations}

This manuscript is based on original work and has not been published in whole or part, in any printed or electronic media, or is under consideration of publication in any printed or electronic media other than as the abstract of conference proceedings.

\section{Authors' Contributions}

All authors contributed equally to the literature search and data analysis.

\section{References}

1. Singer M, Deutschman CS, Seymour CW, Shankar-Hari M, Annane D, Bauer M, et al. The third international consensus definitions for sepsis and septic shock (Sepsis-3). JAMA. 2016;315(8):801. https://doi.org/10.1001/JAMA.2016.0287 PMid:26903338

2. Fleischmann C, Scherag A, Adhikari NK, Hartog CS, Tsaganos T, Schlattmann $\mathrm{P}$, et al. Assessment of global incidence and mortality of hospital-treated sepsis. Current estimates and limitations. Am J Respir Crit Care Med. 2016;193(3):259-72. https://doi.org/10.1164/rccm.201504-0781oc

PMid:26414292

3. World Health Organization. Sepsis. Geneva: World Health Organization; 2018.

4. Hassoun A, Linden PK, Friedman B. Incidence, prevalence, and management of MRSA bacteremia across patient populations-a review of recent developments in MRSA management and treatment. Crit Care. 2017;21(1):211. https://doi.org/10.1186/ s13054-017-1801-3

PMid:28807042

5. Klevens RM, Morrison MA, Nadle J, Petit S, Gershman K, Ray S, et al. Invasive methicillin-resistant Staphylococcus aureus infections in the United States. JAMA. 2007;298(15):1763-71. https://doi.org/10.1001/jama.298.15.1763

PMid: 17940231

6. ECDC. European Centre for Disease Prevention and Control. Antimicrobial Resistance Surveillance in Europe 2014. Annual Report of the European Antimicrobial Resistance Surveillance Network (EARS-Net). Stockholm: ECDC; 2015. p. 118.

7. Tacconelli E, Carrara E, Savoldi A, Harbarth S, Mendelson M, Monnet DL, et al. Discovery, research, and development of new antibiotics: The WHO priority list of antibiotic-resistant bacteria and tuberculosis. Lancet Infect Dis. 2018;18(3):318-27. https:// doi.org/10.1016/S1473-3099(17)30753-3

PMid:29276051

8. Lambert M. IDSA Guidelines on the Treatment of MRSA Infections in Adults and Children; 2011.

9. Casapao AM, Leonard SN, Davis SL, Lodise TP, Patel N, Goff DA, et al. Clinical outcomes in patients with heterogeneous vancomycin-intermediate Staphylococcus aureus bloodstream infection. Antimicrob Agents Chemother. 2013;57(9):4252-9. https://doi.org/10.1128/aac.00380-13

PMid:23796929

10. Cong Y, Yang S, Rao X. Vancomycin resistant Staphylococcus aureus infections: A review of case updating and clinical features. J Adv Res. 2020;21:169-76. https://doi.org/10.1016/j. jare.2019.10.005 PMid:32071785

11. Šundalić S, Ćurčić E, Pavić Ž, Gornik I, Brajković AV. Effect of vancomycin, teicoplanin, and linezolid on renal function of critically ill patients with sepsis. URINE. 2019;1:3-7. https://doi. org/10.1016/j.urine.2020.05.003

12. Paul M, Bronstein E, Yahav D, Goldberg E, Bishara J, Leibovici L. External validity of a randomised controlled trial on the treatment of severe infections caused by MRSA. BMJ Open. 2015;5(9):e008838. https://doi.org/10.1136/ bmjopen-2015-008838

PMid:26362666

13. Emonet $S$, Charles PG, Harbarth $S$, Stewardson AJ, Renzi G, Uckay I, et al. Rapid molecular determination of methicillin resistance in staphylococcal bacteraemia improves early targeted antibiotic prescribing: A randomized clinical trial. Clin Microbiol Infect. 2016;22(11):946.e9-15. 
https://doi.org/10.1016/j.cmi.2016.07.022

PMid:27475737

14. Niederman MS, Chastre J, Solem CT, Wan $Y$, Gao X, Myers DE, et al. Health economic evaluation of patients treated for nosocomial pneumonia caused by methicillin-resistant Staphylococcus aureus: Secondary analysis of a multicenter randomized clinical trial of vancomycin and linezolid. Clin Ther. 2014;36(9):1233-43.e1. https://doi.org/10.1016/j. clinthera.2014.06.029

PMid:25066668

15. Berthaud R, Benaboud S, Hirt D, Genuini M, Oualha M, Castelle M, et al. Early bayesian dose adjustment of vancomycin continuous infusion in children in a randomized controlled trial. Antimicrob Agents Chemother. 2019;63(12):e01102-19. https:// doi.org/10.1128/AAC.01102-19

PMid:31591117

16. Chytra I, Stepan M, Benes J, Pelnar P, Zidkova A, Bergerova T, et al. Clinical and microbiological efficacy of continuous versus intermittent application of meropenem in critically ill patients: A randomized open-label controlled trial. Crit Care. 2012;16(3):R113. https://doi.org/10.1186/cc11405 PMid:22742765

17. Quist SR, Fierlbeck G, Seaton RA, Loeffler J, Chaves RL. Comparative randomised clinical trial against glycopeptides supports the use of daptomycin as first-line treatment of complicated skin and soft-tissue infections. Int J Antimicrob Agents. 2012;39(1):90-1. https://doi.org/10.1016/j. ijantimicag.2011.08.007 PMid:21982144

18. Konychev A, Heep M, Moritz RK, Kreuter A, Shulutko A, Fierlbeck G, et al. Safety and efficacy of daptomycin as firstline treatment for complicated skin and soft tissue infections in elderly patients: An open-label, multicentre, randomized phase Illb trial. Drugs Aging. 2013;30(10):829-36. https://doi. org/10.1007/s40266-013-0114-8 PMid:23990341

19. Fowler VG, Boucher HW, Corey GR, Abrutyn E, Karchmer AW, Rupp ME, et al. Daptomycin versus standard therapy for bacteremia and endocarditis caused by Staphylococcus aureus. N Engl J Med. 2006;355(7):653-65. https://doi.org/10.1056/ nejmoa053783

PMid:16914701

20. Sakoulas G, Moise PA, Casapao AM, Nonejuie P, Olson J, Okumura $\mathrm{CY}$, et al. Antimicrobial salvage therapy for persistent staphylococcal bacteremia using daptomycin plus ceftaroline. Clin Ther. 2014;36(10):1317-33. https://doi.org/10.1016/j. clinthera.2014.05.061

21. Fowler VG, Das AF, Lipka-Diamond J, Schuch R, Pomerantz R, Jáuregui-Peredo $\mathrm{L}$, et al. Exebacase for patients with Staphylococcus aureus bloodstream infection and endocarditis. J Clin Invest. 2020;130(7):3750-60. https://doi.org/10.1172/ JCl136577

PMid:32271718

22. van Hal SJ, Jensen SO, Vaska VL, Espedido BA, Paterson DL, Gosbell IB. Predictors of mortality in Staphylococcus aureus bacteremia. Clin Microbiol Rev. 2012;25(2):362-86. https://doi. org/10.1128/CMR.05022-11

PMid:22491776

23. Shariati $A$, Dadashi $M$, Moghadam MT, van Belkum $A$, Yaslianifard S, Darban-Sarokhalil D. Global prevalence and distribution of vancomycin resistant, vancomycin intermediate and heterogeneously vancomycin intermediate Staphylococcus aureus clinical isolates: A systematic review and metaanalysis. Sci Rep. 2020;10(1):12689. https://doi.org/10.1038/ s41598-020-69058-z

PMid:32728110
24. Ye ZK, LiC, Zhai SD. Guidelines for therapeutic drug monitoring of vancomycin: A systematic review. PLoS One. 2014;9(6):e99044. https://doi.org/10.1371/journal.pone.0099044 PMid:24932495

25. Men P, Li HB, Zhai SD, Zhao RS. Association between the AUC0-24/MIC ratio of vancomycin and its clinical effectiveness: A systematic review and meta-analysis. PLoS One. 2016;11(1):e0146224. https://doi.org/10.1371/journal. pone. 0146224 PMid:26731739

26. Jeurissen A, Sluyts I, Rutsaert R. A higher dose of vancomycin in continuous infusion is needed in critically ill patients. Int $J$ Antimicrob Agents. 2011;37(1):75-7. https://doi.org/10.1016/j. ijantimicag.2010.09.004 PMid:21074374

27. Vandecasteele SJ, de Vriese AS, Tacconelli E. The pharmacokinetics and pharmacodynamics of vancomycin in clinical practice: Evidence and uncertainties. J Antimicrob Chemother. 2013;68(4):743-8. https://doi.org/10.1093/jac/ dks495

PMid:23249839

28. Hermsen ED, Hanson M, Sankaranarayanan J, Stoner JA Florescu MC, Rupp ME. Clinical outcomes and nephrotoxicity associated with vancomycin trough concentrations during treatment of deep-seated infections. Expert Opin Drug Saf. 2010;9(1):9-14. https://doi.org/10.1517/14740330903413514 PMid:20021290

29. Bosso JA, Nappi J, Rudisill C, Wellein M, Bookstaver PB, Swindler J, et al. Relationship between vancomycin trough concentrations and nephrotoxicity: A prospective multicenter trial. Antimicrob Agents Chemother. 2011;55(12):5475-9. https:// doi.org/10.1128/AAC.00168-11

PMid:21947388

30. McKamy S, Hernandez E, Jahng M, Moriwaki T, Deveikis A, Le J. Incidence and risk factors influencing the development of vancomycin nephrotoxicity in children. J Pediatr. 2011;158(3):422-6. https://doi.org/10.1016/j. jpeds.2010.08.019

PMid:20888013

31. Cano EL, Haque NZ, Welch VL, Cely CM, Peyrani $P$, Scerpella EG, et al. Incidence of nephrotoxicity and association with vancomycin use in intensive care unit patients with pneumonia: Retrospective analysis of the IMPACTHAP database. Clin Ther. 2012;34(1):149-57. https://doi. org/10.1016/j.clinthera.2011.12.013

PMid:22284995

32. Schuch $R$, Khan BK, Raz A, Rotolo JA, Wittekind $M$. Bacteriophage lysin CF-301, a potent antistaphylococcal biofilm agent. Antimicrob Agents Chemother. 2017;61(7):e02666-16. https://doi.org/10.1128/AAC.02666-16 PMid:28461319

33. Indiani C, Sauve K, Raz A, Abdelhady W, Xiong YQ, Cassino C, et al. The antistaphylococcal lysin, CF-301, activates key host factors in human blood to potentiate methicillin-resistant Staphylococcus aureus bacteriolysis. Antimicrob Agents Chemother. 2019;63(4):e02291-18. https://doi.org/10.1128/ AAC.02291-18 PMid:30670427

34. Schuch R, Lee HM, Schneider BC, Sauve KL, Law C, Khan BK, et al. Combination therapy with lysin CF-301 and antibiotic is superior to antibiotic alone for treating methicillinresistant Staphylococcus aureus-induced murine bacteremia. J Infect Dis. 2014;209(9):1469-78. https://doi.org/10.1093/ infdis/jit637

PMid:24286983 
35. Watson A, Sauve K, Cassino C, Schuch R. Exebacase demonstrates in vitro synergy with a broad range of antibiotics against both methicillin-resistant and methicillin-susceptible
Staphylococcus aureus. Antimicrob Agents Chemother. 2020;64(2):e01885-19. https://doi.org/10.1128/aac.01885-19 PMid:31712212 